\title{
Pupil Fatalities on Public Transit Buses: A Comparison with School Buses
}

\author{
Lidia P. Kostyniuk \\ University of Michigan, Transportation Research Institute
}

\begin{abstract}
Fatality rates of school-age children on trips to/from school by transit buses (while passengers or pedestrians approaching or leaving the bus) were estimated from existing data and compared with school-bus-related fatality rates. Data from FARS 1996-1998 were used to identify deaths of school-age bus passengers and pedestrians in all crashes during times that children normally travel to/from school. Police crash reports were obtained for the pedestrian deaths an d reviewed for bus involvement and identification of the trip as one to/from school. The average number of pupils killed on such trips on transit buses in the U nited States was 0.3 deaths per year, and possibly as high as 1.7 deaths per year. Using NPTS data to control for exposure, a fatality rate of four deaths per billion pupil trips ( $95 \%$ confidence interval of 1-11) was estimated. Within the precisio $n$ achievable with available data, no recognizable difference between pupil fatality rates by transit buses and school buses was found.
\end{abstract}

\section{Introduction}

There are approximately 57 million children, age 5-18, in the United States (U.S. Census Bureau, 2001) and most of them are pupils in kindergarte $n$ through 12th grade $(\mathrm{K}-12)$. About 23.5 million of these children travel to and from school on 
school buses, ${ }^{1}$ operated or contracted by schools or school districts [National Highway Traffic Safety Administration (NHTSA) 2001a]. In many states, there is no legal mandate to provide pupils with transportation services and because of other funding priorities and limited budgets, some schools and school districts look to public transit buses as an alternative to school buses. Indeed, many urban public transportation systems have special fares for students, and adj ust their schedules and routes to meet the demand for trips to and from school. The number of children who travel to and from school on common carrier buses operated by public transit agencies is not known, but was reported in 1996 to be about two million (National Association of State Directors of Public Transportation Services 1996). Although the number of fatalities and injuries on public transit systems is very low (e.g., see NHTSA 2001b), most riders are adults, and communities considering public transit for pupil transportation have questions about the safety of children traveling on these buses. Periodically, a tragic death of a child on the way to or from school by public transit bus intensifies these quest ions (e.g., National Transportation Safety Board 1997).

Children traveling either by school bus or transit bus are expo sed to risks of injury or death as passengers on the bus as well as pedestrians approa ching or leaving the bus. There are, however, more measures to reduce these risks for children on school buses than for children on public transit buses. For exa mple, many of the Federal Motor Carrier Safety Standards (FMCSS) that apply to bu ses have additional requirements for school buses, including outside mirrors that allow a seated driver to see along both sides of the bus, amber and red warning lights for use when loading and unloading passengers, emergency exits, and spe cial fuel system requirements. In addition, four FMCSS are unique to school buses, including minimum structural strength for rollover protection, bus body joint strength, high-backed and well-padded passenger seats, and a pedestrian s afety system consisting of a stop signal arm to protect pupils in the bus loading and unloading area (Code of Federal Regulations 49 CFR 571.3, 2002). Furthermore, traffic laws of all 50 states and the District of Columbia require motorists to stop when they encounter a school bus that is loading or unloading children (Ham ada 1999). There are no similar traffic rules for public transit vehicles.

Although the extra safety precautions associated with school bu ses seem to indicate greater safety on the school bus system, a comparison of the rates of fatalities and injuries sustained by children on the way to and from school by both bus systems would provide a more definitive answer to the question about pupil 
safety on public transit bus systems. A direct comparison of such rates, however, is challenging because the information available from national vehicle crash databases is not sufficient to perform the necessary statistical an alysis, so indirect methods must be identified and used. Furthermore, some indirect met hods may be suitable for estimating fatalities but not injuries, thus calling for separate approaches and analyses.

This article explores the differential effects on safety of chi ldren traveling to and from school (henceforth called school trips) by public transit buses and by school buses. The objectives are (1) to obtain on a nationwide basis, comparable estimates of fatality rates ${ }^{2}$ of pupils on school trips by these two modes using existing data sources, and (2) to identify the shortcomings and uncertainties that come from using these data. The measures selected for assessing safe ty of school trips are the numbers and rates of fatalities sustained by pupils as pass engers on public transit buses and school buses, and as pedestrians when approac hing or leaving either type of bus. Pedestrian fatalities include those with di rect and indirect involvement of the bus, with direct involvement including cases in which the victim was struck by the bus that he or she was approaching or leaving, and indirect involvement including cases in which the child was struck by a vehicle other than the bus.

The rest of this article is organized as follows. Potential dat a sources for fatalities of children on school trips on public transit vehicles and school buses are assessed in the next section. Measures and data sources of exposure are exa mined in the third section. Methods used for estimating the numbers and rates of $p$ upil fatalities on school trips are described in the fourth section. Results are presented in the fifth section. The overall findings are discussed in the last section.

\section{Data Sources}

The first step in this study was to identify data sources that record fatal crashes involving pupils on school trips. Ideally, such sources would identify the victim as a pupil, the trip as a school trip, and the vehicle as a school bus or public transit bus. Such information should be available for bus-related crash es involving other vehicles as well as pedestrians.

For fatal crashes, the Fatality Analysis Reporting System (FARS; NHTSA, 1999a) is the most complete database, covering all fatal motor vehicle tr affic crashes nationwide and subject to thorough quality controls. FARS has detailed vehicle-body codes that allow clear differentiation of school buses and public transit buses. 
FARS also has a special code to indicate that a school bus was involved in a crash. Crashes involving school buses with other vehicles or with pede strians are coded as school-bus related. Pedestrian crashes in which a child was struck by another vehicle while approaching or leaving the school bus are also coded as school-bus related, if the lights on the school bus were flashing. Cases in which the victim was a passenger on a public transit bus or was struck by the bus ca $n$ be easily identified in FARS, but there are no codes to identify a victim as a pupil on a school trip. There are also no elements for coding the indirect involvement of public transit buses in any pedestrian crash. It is feasible to identify victims as possible pupils by determining if the victim was of school age, and if the crash o ccurred at the time a child would be traveling to or from school, but there is no way of assessing whether a public transit bus was indirectly involved.

Other electronic data sources were examined to determine if the y contained information about indirect involvement of public transit buses in pedestrian deaths or if victims could be identified as pupils on a school trip. A mong the data systems examined were: the National Accident Sampling System (NASS) Gen eral Estimates System (NHTSA 1999b), NASS System Crashworthiness Data System (NHTSA 1998), NASS Pedestrian Crash Data Study (NHTSA 1997), Crash Out come Data Evaluation System (NHTSA 1996a, the National Transit Database (Federal Transit Administration 1999) and state crash data files (NHTSA 1999c). None of these data sources could provide information on the indirect involvement of public transit buses in pedestrian crashes. With the exception of Colorado's state crash data, which has a provision for identifying a victim as a child on a school trip, none of the data sources could identify a victim as a pupil on a school trip.

Several nonelectronic data sources were also considered including annual national surveys of school bus loading and unloading accidents published by the Kansas State Department of Education (KSDOE 1996,1997,1998, 1999) and original hardcopy police crash reports (PCRs). The KSDOE reports contain much information about direct and indirect involvement of school buses, but provide little information about public transit bus crashes. The PCRs (from which electronic crash records are coded) include narratives, crash diagrams, witness statements, and other information about the crash. Thus, additional information about cases in FARS electronic data can be found in these PCRs and may provide enough information to determine if a child was on a school trip, and also to determine if a public transit bus was indirectly involved. 
The most promising source for comparing fatalities on public transit buses to those on school buses appears to be a combination of FARS electronic data and PCR materials. Fatal crashes involving pupil passengers on school buses and pupil pedestrians, whether they were struck by the school bus or by a nother vehicle when approaching or leaving the school bus, can be obtained from FARS electronic data. Cases in which victims were school-age passengers of public transit buses or school-age pedestrians struck by public transit buses can also be identified directly from FARS electronic data. Indirect involvement of public transit buses in pupil fatalities may be determined through the review of hard-copy PCRs of cases identified by screening FARS data. Because indirect involvement of a bus in a crash occurs when a pedestrian, approaching or leaving the bus, is struck by another vehicle, the set of all vehicular crashes involving ped estrians of school age that occurred at the time that children regularly travel to and from school should also contain those cases in which public transit buses were indirectly involved.

\section{Exposure}

\section{Measures}

To calculate rates of crashes involving pupils on school trips, a suitable measure of exposure had to be selected. This was done by examining the typ es of risks pupils are exposed to on school trips by bus, the measures of these risks, the relative magnitude of these risks, and the availability of meaningful da ta.

Children on school trips by bus are exposed to the risk of two types of crashes: the risk of a crash while they are passengers on the bus and the ri sk of being struck by the bus or another vehicle when they are approaching or leaving the bus. Pupilmiles of travel is an appropriate exposure measure for the first type of crash. Crashes of the second kind can occur only at two points during each tri p; that is, when the pupil gets on or off the vehicle. Thus, the number of pupil tri ps is an appropriate exposure measure for the second type of crash.

NHTSA (1999d) reports that in school-bus-related crashes, three times as many pedestrians as passengers are killed. Because the overall number of fatalities aboard public transit buses is small, the number of pupil fatalities on board transit buses is also small. Therefore, it is plausible to expect that the risk to children is greater when they are approaching and leaving a public transit bus than when they are passengers on that bus. Furthermore, estimating pupil-miles of travel would involve estimating distributions of the pupil-trip lengths and pu pil bus occupancies over bus routes, and any proxy for pupil-miles would at best be a crude approxi- 
mation. These challenges led to the selection of pupil trips as the single exposure measure for this study.

\section{Exposure Data}

School bus ridership by state is available from the National As sociation of State Directors of Pupil Transportation Services (Bobbitt Publications 2002). The challenge in this study was to find a source of comparable pupil ridership on public transit systems. Several sources were examined including the National Transit Database (Federal Transit Administration 1999), American Public Transportation Association (APTA), public transit systems, and the National Personal Travel Survey (NPTS; Research Triangle Institute and Federal Highway Administration 1997).

The National Transit Database does not have student ridership nor does it distinguish riders by age. APTA does not routinely collect student ridership information. While many public transit agencies collect student ridership data, several were contacted and indicated that their legal departments would not allow them to provide data for this study.

The NPTS is the national database of travel patterns and can be used to estimate trips by age group by purpose by modes, including the number of school trips by various modes. The latest available NPTS data at the time of th is study were from 1995. There are several problems, however, with using NPTS data to estimate the number of pupil trips on public transit buses. One problem is that NPTS has codes for three types of buses: intercity bus, school bus, and bus. This distinguishes school buses from other buses, but does not distinguish public transit buses from other types of buses. Although the buses coded as "b us" in NPTS for school trips are most likely public transit buses, the possibility of other types of buses (e.g., private bus, shuttle service bus) cannot be ruled out.

Another problem may be how accurately actual school trips can be estimated from the NPTS data. The NPTS survey collects data from a nation al sample of households on all personal travel, of which school trips are a very small part. The actual number of school trips in the sample is relatively small, which suggests that the uncertainty associated with national estimates of these trips from NPTS is large.

Despite these shortcomings, NPTS was by far the best source of national modal information for school trips and using NPTS for pupil trips for both school buses and public transit buses provides comparable estimates. NPTS was, therefore, 
selected to provide a national estimate of pupil transit bus ridership and school bus ridership for this study.

\section{Method for Estimating Pupil Fatalities and Rates}

Because the number of fatalities involving school buses and tra nsit buses is small, one year of FARS data would not be sufficient for this analysis. Accordingly, three years of FARS data (1996-1998) were used. The following set of criteria was used to identify potential cases involving children on school trips by school bus and by public transit bus.

Time Criteria

- September through June, excluding Labor Day, Thanksgiving and the following Friday, Christmas, New Year's Day, and the week between Christmas and New Year's Day, and Memorial Day

- Monday though Friday

- Hours: 6:00-8:59 and 14:00-16:59

- Victim criteria

- Age 5-18 years

- Occupant of a bus or van ${ }^{3}$ or a pedestrian in a crash with any vehicle

- Vehicle criteria, if victim is not a pedestrian

- School bus or van, operated by a school, school district, or private contractor

- Transit bus or van, operated by public transit system

Applying these time criteria may exclude crashes on some school trips that occurred during regular school hours, late in the day, on weekends, or during summer school. Furthermore, because vacation periods and holidays vary between states and often within a state by school district, use of these time criteria may exclude some cases that occurred on a school day and retain oth ers that did not. However, examination of the distributions of school-age fatalities in school-bus related crashes recorded in FARS by month, day, and hour (Kostyniuk and Joksch 2002) showed that these criteria captured most of the cases. Time periods identified by the time criteria are referred to as regular school-tra vel hours in the rest of this article. 


\section{Pupil Passenger Fatalities}

School-age passenger fatalities were identified directly from the FARS electronic data files and are shown in Table 1. There were 84 crashes involving buses, of which 10 involved at least 1 school-age passenger fatality. There were 9 crashes involving school buses in which 12 children were killed. There were no sc hool-age children killed as passengers on public transit buses during regular sch ool-travel hours. However, 1 school-age passenger was killed on a bus coded in FARS as "other" bus.

\section{Table 1. Number of Crashes Involving Buses During Regular School-Travel Hours}

\begin{tabular}{|c|c|c|}
\hline Rus Type & $\begin{array}{l}\text { Na of } \\
\text { Constives }\end{array}$ & 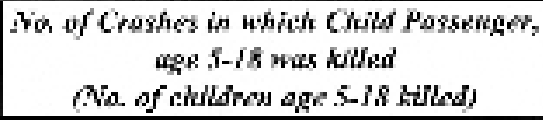 \\
\hline Scloos bes & 75 & $\begin{array}{c}9 \\
(12) \\
\end{array}$ \\
\hline Publec Irausit bex & 5 & 0 \\
\hline Cher bus. & 3 & $\begin{array}{c}1 \\
(1)\end{array}$ \\
\hline Uakwowe bus & 1 & $\begin{array}{c}0 \\
\text { (0) }\end{array}$ \\
\hline Tolial & 34 & $\begin{array}{r}10 \\
113\rangle \\
\end{array}$ \\
\hline
\end{tabular}

5\%ucy: FÂR3. 1993-1888

\section{Pupil Pedestrian Fatalities Near Buses}

Analysis of FARS electronic data from 1996-1998 found 401 fatal crashes involving pedestrians age 5-18 that occurred during regular school-travel hours. The PCRs for all cases were requested from the states through NHTSA. Of the 401 cases, PCRs were available for 388. Review of these narratives found t hat in 14 of the 388 cases, the person killed in the crash was not a pedestrian age 5-18, but some other person involved in the crash. These cases were dropped from further consideration. The PCRs of the remaining 374 cases were carefully read to determine if the victim was on the way to or from school, and if any type of bus was involved in the crash. A summary of these results is contained in Table 2.

Further review of the 374 cases identified 73 cases in which bu ses were specifically mentioned (school buses in 58 cases; public transit buses or ot her buses-e.g., "city bus" or just "bus" in 15 cases). Of these 73 cases, 24 were dropped from 


\section{Table 2. Initial Sorting of the 401 Cases Involving Pedestrians Age 5-18 During Regular School-Travel Hours}

\begin{tabular}{|c|c|c|c|}
\hline PCRs aot available & & & 13 \\
\hline Fatnl viction rot nise $5-18$ & & & 14 \\
\hline \multirow[t]{8}{*}{ Fatal viclim ase S-lK } & & & 374 \\
\hline & Wias victim on aclool trip? & & \\
\hline & Yes & 12.3 & \\
\hline & Likely & 36 & \\
\hline & Not Jibcly & 12 & \\
\hline & No & 56 & \\
\hline & Nol enisught in liormabua & 948 & \\
\hline & Total & 374 & \\
\hline Total & & & 401 \\
\hline
\end{tabular}

Boves: Eased an rovich at FCRs.

further consideration because they were not relevant to study (e.g., the crash occurred near a bus stop with no bus present; a bus happened to be in the vicinity but was not involved in the crash; a pedestrian was struck by a random vehicle in the traffic stream that happened to be a bus). The remaining 48 crashes were cases in which school-age pedestrians were killed while approaching or leaving a school bus or public transit bus. Table 3 shows the distribution of these cases by type of pedestrian-vehicle interaction.

\section{Exposure}

Table 4 shows the numbers of pupil-trips during regular school-travel hours based on NPTS. Pupils who drove themselves were excluded and the smal I number of trips by intercity bus is included in the "other/unknown" category. There were an estimated 4.6 billion pupil-trips by school bus and 0.3 billion pupil-trips by bus. The latter category is referred to as the nonschool bus category in the rest of this article and consists mostly, but not exclusively of trips by pu blic transit buses. 


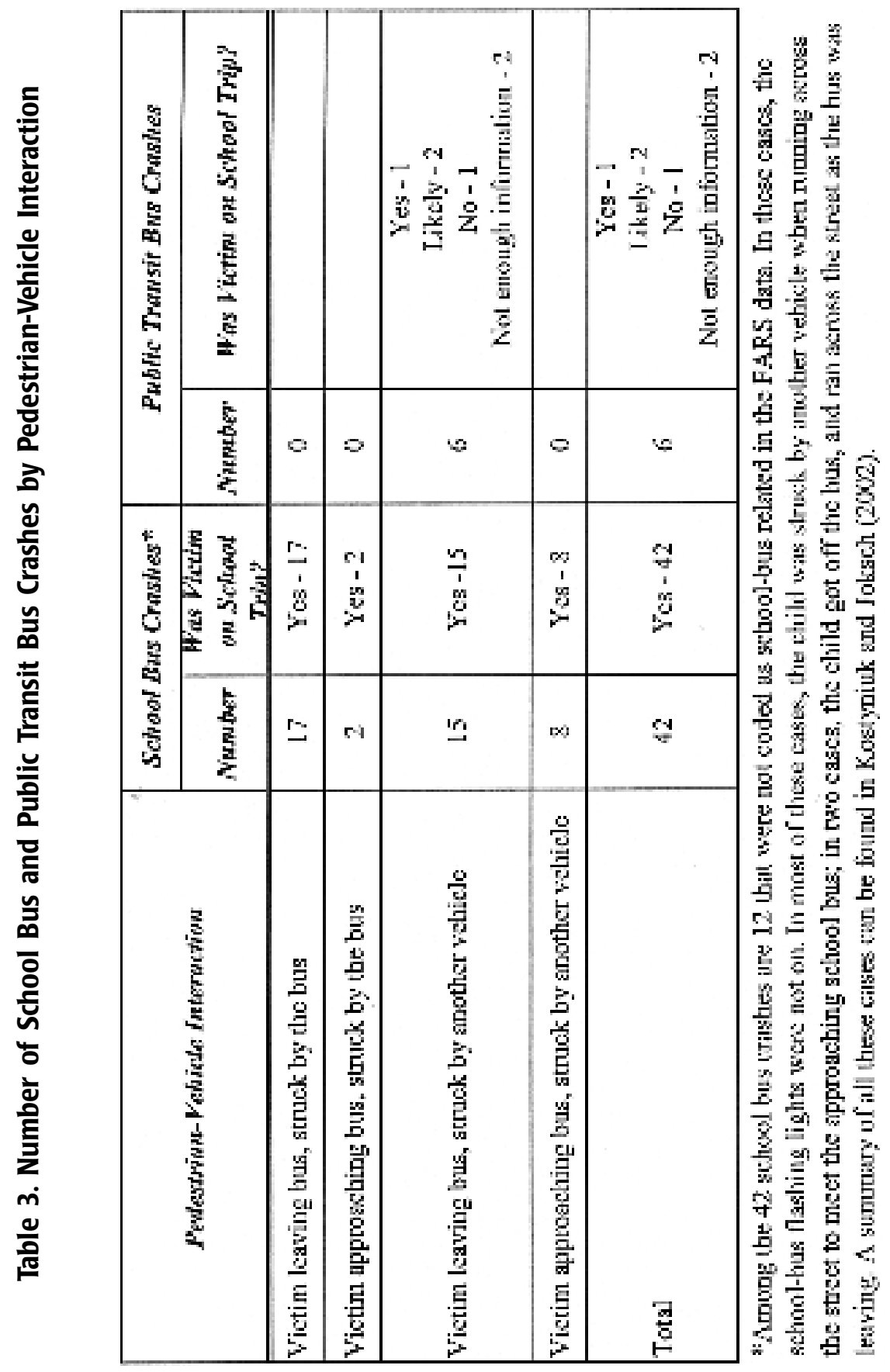


Table 4. Number (in billions) of Trips between Home and School by Children, Age 5-18 During Regular School-Travel Hours from September through June

\begin{tabular}{|c|c|c|c|}
\hline Ifowle & $\begin{array}{c}\text { Tu Sc:froul } \\
6:(W)-8: 59 \mathrm{Hr}\end{array}$ & $\begin{array}{l}\text { Srour Sicfrowl } \\
18: 00-16: 59 \mathrm{Hr}\end{array}$ & $\begin{array}{c}\text { Tutal } \\
\text { To of From School }\end{array}$ \\
\hline 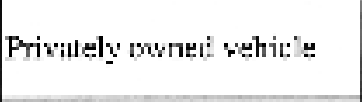 & $\begin{array}{c}2.738 \\
(44.18)\end{array}$ & $\begin{array}{c}1.528 \\
130.721\end{array}$ & $\begin{array}{r}4.266 \\
(38.1 \%) \\
\end{array}$ \\
\hline Scliosl bus & $\begin{array}{l}2.299 \\
(37.0 \%)\end{array}$ & $\begin{array}{c}2.312 \\
(4 ; .4 \%)\end{array}$ & $\begin{array}{c}4.611 \\
(41.2 \%)\end{array}$ \\
\hline Walk & $\begin{array}{c}0.713 \\
(11.56)\end{array}$ & $\begin{array}{c}0.725 \\
(14.6 \%)\end{array}$ & $\begin{array}{c}1.438 \\
(12.8 \%)\end{array}$ \\
\hline $\begin{array}{l}\text { Rus (ronschosl hus, } \\
\text { incluxlex puthlic transit bus) }\end{array}$ & $\begin{array}{l}0.158 \\
(3.5 \%)\end{array}$ & $\begin{array}{l}0.139 \\
(2.849)\end{array}$ & $\begin{array}{l}0.297 \\
2.7 \% 1\end{array}$ \\
\hline Bicycls & $\begin{array}{l}0.1977 \\
(1.3 \%)\end{array}$ & $\begin{array}{l}\text { U.UG } \\
11.24 .)\end{array}$ & $\begin{array}{l}0.142 \\
(1.3 \% 1\end{array}$ \\
\hline Ot'ıer'L Irıknown & $\begin{array}{l}0.225 \\
\{3.6 \%)\end{array}$ & $\begin{array}{l}u .214 \\
(4.3 \%)\end{array}$ & $\begin{array}{l}0.438 \\
(3.90 \mathrm{j})\end{array}$ \\
\hline Twial & $\begin{array}{c}6.21 \\
(130 .(1+15)\end{array}$ & $\begin{array}{c}4.98 \\
(21010 \times 5)\end{array}$ & $\begin{array}{c}11.19 \\
\langle 100.02 \%\end{array}$ \\
\hline
\end{tabular}

Sauce: INPTS 1955.

\section{Results}

\section{Passenger Fatalities}

Passenger fatalities are shown in Table 5. Between 1996-1998, there were 12 pupil fatalities in nine crashes in which a pupil was killed while a passenger on a school bus during regular school-travel hours (four deaths annually). Assuming that the crashes are Poisson distributed, ${ }^{4}$ the 95 percent confidence range is from 2.1 to 7.0. Dividing these numbers by 4.6 billion pupil-trips per year by school bus gives a rate of 0.9 pupil passenger deaths per billion pupil trips, with a 95 percent confidence interval of 0.5 to 4.5 .

There were no school-age passenger deaths on public transit bus es during regular school-travel hours during 1996-1998. However, there was one crash and one school-age passenger death on board a bus coded in FARS as "other." Assuming a Poisson distribution for crashes and school-age passenger deaths gives a 95 per- 
cent confidence interval from 0.03 to 1.9 passenger deaths per year on nonschool buses. Dividing by 0.3 billion pupil-trips by nonschool bus per year, gives a rate of 1.1 pupil passenger deaths per billion pupil trips, with a 95 percent confidence interval from 0.1 to 6.2 .

If only trips by public transit bus are considered, no school-a ge passenger fatalities were observed during regular school-travel hours. This gives a 95 percent confidence interval for the number of fatalities from 0 to 1.2. Beca use there was no exposure measure specifically for public transit buses, the num ber of pupil-trips per year by nonschool buses was used to estimate the rate. The resulting rate was 0 with a 95 percent confidence interval of 0 to 4 passenger fat alities per billion pupil school trips by public transit bus.

Table 5. Number and Rate of Pupil Passenger Fatalities on School Buses, Nonschool Buses, and Public Transit Buses During Regular School-Travel Hours

\begin{tabular}{|c|c|c|}
\hline Vefric:Le Type & $\begin{array}{c}\text { Pupis Paxwergars Fofalities/I'r } \\
\text { (ys\% confuterce interval) }\end{array}$ & 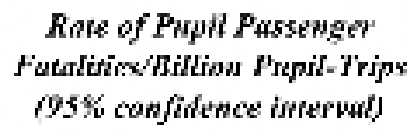 \\
\hline Eohool bus & $\stackrel{4}{(2.1-7.0)}$ & $\begin{array}{c}0.9 \\
(0.5-4.5\rangle\end{array}$ \\
\hline Norsebussl hus & $\begin{array}{c}0.3 \\
(\infty 5-1.9)\end{array}$ & $\begin{array}{c}1.1 \\
(0.1-6.2)\end{array}$ \\
\hline l'ubiic transit bus & $\begin{array}{c}\theta \\
\langle 2.12-12\rangle\end{array}$ & $\begin{array}{c}0 \\
(a n-40)\end{array}$ \\
\hline
\end{tabular}

\section{Pedestrian Fatalities}

School Buses. There were 42 pupil deaths near school buses between1996-1998 (14 pupil deaths annually). The resulting fatality rate is 3.0 pupil fatalities per billion pupil-trips with a confidence interval of 2.2 to 4.1 (Table 6). 


\section{Table 6. Estimate of Number and Rates of Pupil Pedestrians Killed Near School Buses During Regular School-Travel Hours}

\begin{tabular}{|c|c|}
\hline 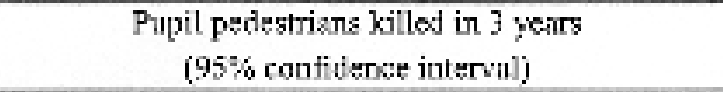 & $\begin{array}{c}42 \\
(30,3-56,8)\end{array}$ \\
\hline 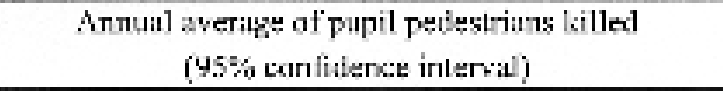 & (11).1-18.9) \\
\hline $\begin{array}{l}\text { Rale of pupil pedestriars killed por billion pupil trips } \\
\text { (95\% confidenec range) }\end{array}$ & $\begin{array}{c}3 \\
\{2.2-4.1\}\end{array}$ \\
\hline
\end{tabular}

Public Transit Buses. In the pedestrian cases involving public transit buses or other buses in which school-age pedestrians were killed during regular schooltravel hours, all buses were public transit buses. However, the estimate of numbers and rates of pupil fatalities depends on the level of uncertain ly that is accepted in determining if the trip was indeed a school trip.

It was known with certainty in only one incident that the child was on the way to school. If cases classified as definitely or likely to be school trips are assumed to be school trips, the number of pupil fatalities near public transit buses increases to three. If the two cases for which it was not possible to determ ine if the victim was on a school trip are included, the number of pupil fatalities near public transit buses in the three-year period increases to five. Table 7 shows the three different estimates for fatalities and rates near public transit buses.

\section{Table 7. Estimates of Number and Rate of Pupil Pedestrians Killed Near Public Transit Buses During Regular School-Travel Hours}

\begin{tabular}{|c|c|c|c|}
\hline & \multicolumn{3}{|c|}{ Cikild Hes wa School Trip } \\
\hline & Definäredy' & $\begin{array}{l}\text { Degfincitaly ar } \\
\text { Likety }\end{array}$ & $\begin{array}{l}\text { Definitcilv } \\
\text { Lithels or } \\
\text { Posstoty }\end{array}$ \\
\hline $\begin{array}{c}\text { l’upil podestuians kllod in } 3 \text { yests } \\
\text { (95\% confidenes interval) }\end{array}$ & $\begin{array}{c}1 \\
(0)-5 \Delta)\end{array}$ & $\begin{array}{c}3 \\
(0.5-8.5)\end{array}$ & $\begin{array}{c}5 \\
(1.6-11.7)\end{array}$ \\
\hline 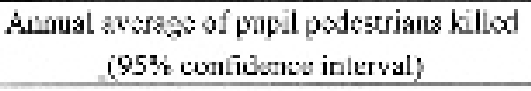 & $\begin{array}{c}0.3 \\
(0.03-1.9) \\
\end{array}$ & $\begin{array}{c}1 \\
(0.2 \cdot 2.5) \\
\end{array}$ & $\begin{array}{c}1.7 \\
\langle 0.5-3.9\rangle \\
\end{array}$ \\
\hline 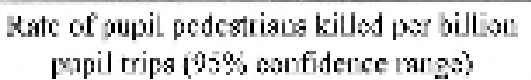 & $\begin{array}{c}1.1 \\
{[0.1-6.2)}\end{array}$ & $\begin{array}{c}3.3 \\
0.9 .81\end{array}$ & $\begin{array}{c}5.6 \\
(1.8-13.0)\end{array}$ \\
\hline
\end{tabular}


Of the three estimates, the first is likely to be conservative and can serve as a lower bound. The second estimate is most plausible because it is base $d$ on the assumption that cases with trips judged as likely to a school trip are indeed so. The resulting estimate gives a pupil fatality rate near public transit buses that appears to be similar to the fatality rate near school buses. The third estim ate includes cases that may only possibly be school trips and yields essentially a worst-case estimate that may serve as an upper bound.

Table 8 shows the full range of estimates for the total (passenger and pedestrian) pupil fatality rates for public transit buses. There are two se ts of estimates. The first set uses the total number of deaths on or near all nonschool bu ses and the second uses only deaths on or near public transit buses. The estimates of the rate of pupil fatalities per billion school trips by nonschool buses range from 2.2 to 6.7, depending on the level of uncertainty accepted in the identificat ion of school trips. If only known public transit bus cases are included in the estimation, this range is from 1.1 to 5.6 .

\section{Table 8. Upper and Lower Bounds of Estimate of Rate of Pupil Passengers and Pedestrians Killed on School Trip by Nonschool Buses and Public Transit Buses}

\begin{tabular}{|c|c|c|c|c|c|c|}
\hline \multirow{3}{*}{ 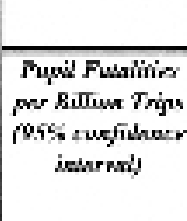 } & \multicolumn{3}{|c|}{ 'Vansmitad Juses } & \multicolumn{3}{|c|}{ Matis Yrousen Jases } \\
\hline & 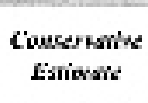 & 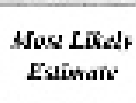 & $\begin{array}{l}\text { Hors Cass } \\
\text { Esiowsic }\end{array}$ & $\begin{array}{c}\text { Constriate } \\
\text { Estimete }\end{array}$ & $\begin{array}{l}\text { Afoes Lixal } \\
\text { Estivant: }\end{array}$ & $\begin{array}{l}\text { Worse Cias } \\
\text { Estwate }\end{array}$ \\
\hline & $\begin{array}{c}2.2 \\
02-9.91\end{array}$ & $\begin{array}{c}4.4 \\
0.1-11.3)\end{array}$ & $\begin{array}{c}6.7 \\
(20-150)\end{array}$ & $\begin{array}{c}1.1 \\
0.1-23\end{array}$ & $\begin{array}{c}3.3 \\
(0.7-9)\end{array}$ & $\begin{array}{c}56 \\
1.8 .8-13.21\end{array}$ \\
\hline
\end{tabular}

Figure 1 shows the most likely estimates of rates of transit-bu s-related pupil fatalities to the rate of school-bus-related fatalities and their $95 \mathrm{t} h$ percent confidence intervals. These average rates do not appear to be different from each other. This is true whether the pupil fatality rate from school-bus-related cases is compared to the rate for public transit buses or to the rate for the broade $r$ category of nonschool buses, which includes not only the transit vehicles but also buses coded in FARS as "other." However, because the number of cases is very small, any differences would have to be very large to be recognizable. 


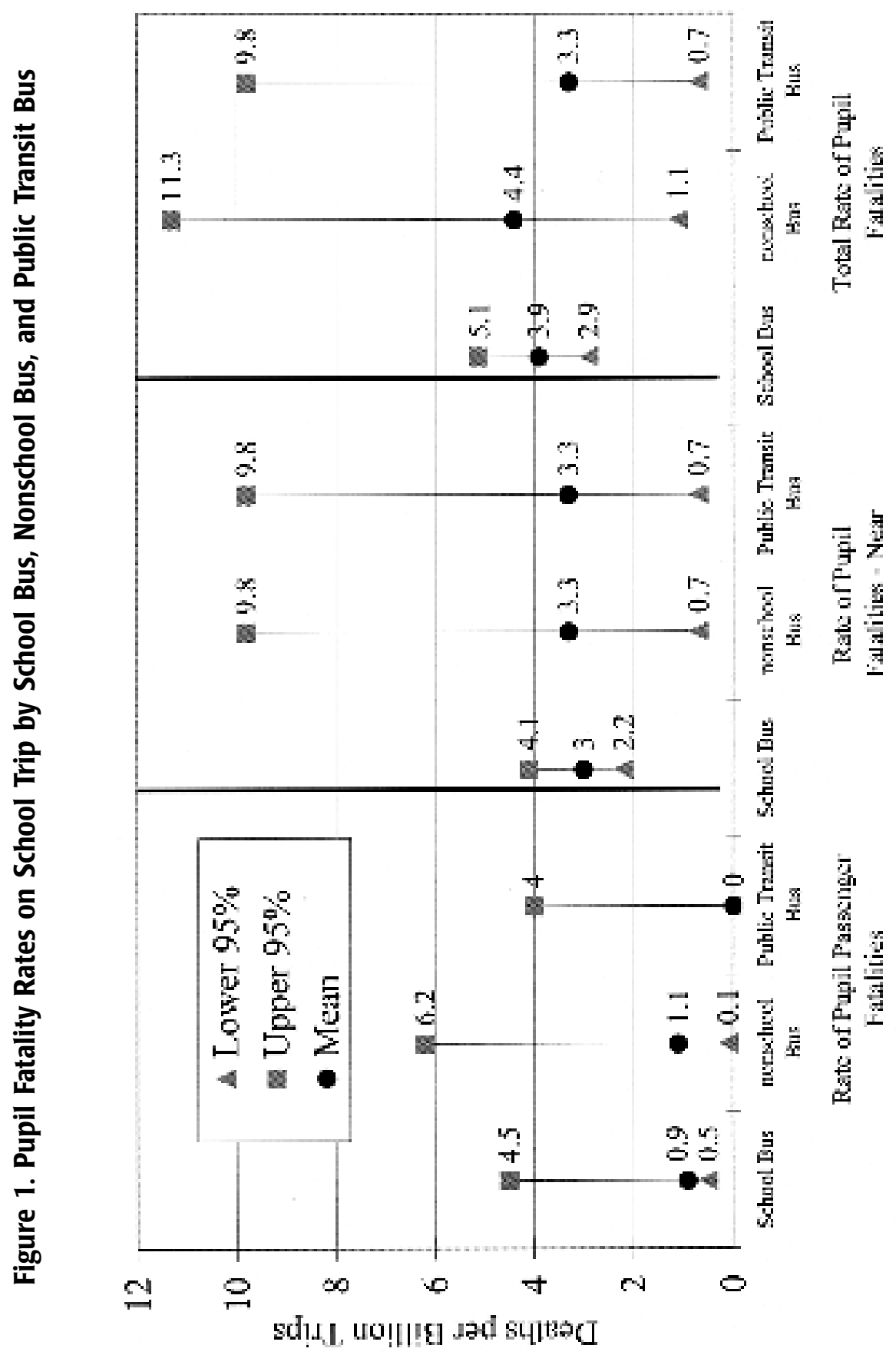




\section{Findings}

Fatality rates for grade $\mathrm{K}-12$ pupils on public transit buses an $\mathrm{d}$ school buses on school trips were estimated based on fatalities in FARS data files, review of police crash reports, and exposure information from NPTS data. The ove rall finding of this study is that, within the precision achievable with the available data and available effort, there is no recognizable difference between pupil fatality rates by school buses and by public transit buses. Both rates were about four fatalities per billion pupil trips.

While there was no recognizable difference in rates, the differ ence in absolute numbers was large because many more children are transported to and from school by school buses than by public transit buses. The nation wide average number of pupils in the killed going to or from school as bus pass engers or pedestrians approaching or leaving the bus was found to be 0.3 deaths per year, and possibly as high as 1.7 deaths per year (depending on the uncertainty accepted in interpreting crash records) for public transit buses, and 18 for sch ool buses. The very low number of pupil deaths by public transit bus greatly limits the statistical precision of attainable estimates. Precision could be increased by using data from longer time periods, perhaps as long as 20 years. However, policies and practices change over such long periods, introducing other sources of uncertainty.

In addition to this basic difficulty caused by small numbers, the process of estimating these rates was particularly challenging because of limi tations in data availability. National and state motor vehicle crash databases do not contain all the information needed to identify pupil fatalities and even the or iginal police crash reports do not always have this information. The lack of exposu re data presents another problem. The NPTS was the most comprehensive source of national data on school trip modes available but because it groups public tra nsit buses together with all other nonschool buses, it was not possible to estimate pupil trips or other exposure measures for public transit buses alone from these dat $a$.

Sufficiently detailed data would reduce the uncertainty in futu re estimates of pupil fatality rates on public transit buses. Key pieces of information needed are identification of a pupil on a school trip and the indirect involvement of public transit buses in pedestrian crashes (crashes in which the victim was struck by another vehicle while approaching or leaving the bus). National and state motorvehicle crash data files identify crashes as school-bus related if a school bus was 
directly or indirectly involved. A similar code for transit-related crashes should be invaluable for identifying the cases involving public transit buses.

More detailed exposure data is also critical for more precise estimates of pupil fatalities by public transit bus. The NPTS, although not fully compatible with the definitions of public transit buses, was the best nationwide es timate available for the present study, because the National Transit Data Base maintained by the FTA does not contain information on pupil ridership. Most large public transit systems have information on pupil ridership and could report it, a lthough they are not required to do so.

Changing national crash databases or the national transit syste $m$ reporting requirements is not a simple undertaking. An alternative approach could address the question of relative safety of pupil transportation by the two bus modes. A study could be designed to collect information about school trip crashes at the school district level. Such a study would involve developing an appropriate sample and then recruiting a number of school districts, with some using school buses, some using transit buses, and some using both types of buses. The school districts would report all crashes involving their pupils on school trips by school bus and by transit bus on special forms, which they would complete with the cooperation of the police agency investigating the crash. The advantage of this approach is that the exposure and crash information could be fully matched for the sample of pupils. This approach could also be used to collect injury information. Further, it need not be limited to the bus modes but could also be used to determine the safety of the school trip by all modes of travel.

The relative risk of children's travel to and from school by various modes is an important issue. Only by knowing the relative risks and safety records of each travel mode, can communities, parents, and school districts make informed choices that balance safety, community needs, and resources. 


\section{Endnotes}

149 CFR 571.3 (Code of Federal Regulations 2002) defines a scho ol bus as a bus that is sold, or introduced into interstate commerce, for purposes that include carrying students to and from school and related activities, but does no $t$ include a bus designed and sold for operation as a common carrier in urban tran sportation.

ANSI 16.1, Manual on Classification of Motor Vehicle Traffic Accidents defines a school bus as a vehicle used for the transportation of any school pupil at or below the 12th grade level to or from a public or private school or school-related activity. This vehicle is not a school bus while on trips which involve the transportation exclusively of other passengers or exclusively for other purposes. It is a school bus only if it is externally identifiable by the following characte ristics: (1) its color is yellow, (2) the words "school bus" appear on the front and rear, (3) flashing red lights are located on the front and rear, and (4) lettering on both sides identified the school or school district served, or the company operating the bus.

${ }^{2}$ The research on which this article is based did investigate the feasibility of estimating pupil injuries on the school trip by transit bus. Because of type and quality of data available, the methods for obtaining nationwide estimates of pupil injuries were very different from those used to obtain fatality estimates and are not reported in this article.

${ }^{3}$ The vehicle category "van" was included in these criteria beca use there are separate codes in FARS for van-based school bus and van-based public transit bus. Van-based school buses are included in the school bus category, and public transit vans are included in the public transit bus category in this study.

${ }^{4}$ The assumption of a Poisson distribution for passenger deaths is somewhat tenuous because multiple deaths in one crash may not be indepen dent.

\section{Acknowledgments}

This article is based on work by the author and Hans C. Joksch of the University of Michigan Transportation Research Institute (UMTRI) sponsored by the Federal Transit Administration under TCRP Project J-6 Task 30, Data Collection for Pupil Safety on Transit Bus Systems. The author thanks Jean T. Shope and Lisa J. Molnar of UMTRI for their helpful comments and suggestions in the preparation of this 
article. The opinions and conclusions expressed or implied in this article are those of the author and not necessarily of the sponsoring agencies.

\section{References}

ANSI 16.1. 1996. Manual on classification of motor vehicle traffic accidents.

Bobbit Publications. 2002. State by State Transportation Statistics. http:// www.schoolbusfleet.com. Accessed July 24, 2002.

Code of Federal Regulations 49 CFR 571.3. Federal Motor Vehicle Safety Standards, as of October 1, 2002.

Federal Transit Administration. National transit database. 1999. http:// www.fta.dot.gov.ntl/database.htm. Accessed October 10, 1999.

Hamada, K., ed. 1999. Digest of motor laws. Heathrow, FL: AAA Traffic Safety Department.

Kansas State Department of Education. 1996. School bus loading \& unloading survey, 1995--96 school year. Topeka: School Bus Safety Education Unit.

Kansas State Department of Education. 1997. School bus loading \& unloading survey, 1996-97 school year. Topeka: School Bus Safety Education Unit.

Kansas State Department of Education. 1998. School bus loading \& unloading survey, 1997-98 school year. Topeka: School Bus Safety Education Unit.

Kansas State Department of Education. 1999. School bus loading \& unloading survey, 1998-99 school year. Topeka: School Bus Safety Education Unit.

Kostyniuk, L. P, and H. C. Joksch. 2002. Pupil safety on transit bus systems: A comparison with school buses, Report UMTRI-2002-15. Ann Arbor: University of Michigan Transportation Research Institute.

National Association of State Directors of Pupil Transportation Services. 1996. www.stnonline.com/stn/schoolbussafety.positionpapers/nasdpts_transit.htm. Accessed February 11, 2002.

Nation Highway Traffic Safety Administration. 1996a. The crash outcome data evaluation system (CODES). DOT HS 808338 NHTSA Technical Report. Washington, D.C.: U.S. Department of Transportation. 
National Highway Traffic Safety Administration. 1996b. Traffic safety facts-1995. DOT HS 808 471, Washington, D.C.: U.S. Department of Transportation.

National Highway Traffic Safety Administration. 1997. National automotive sampling system (NASS) Pedestrian Crash Data Study (PCDS), 1996. Data Collection, Coding, and Editing Manual. Washington, D.C.: U.S. Department of Transportation.

National Highway Traffic Safety Administration. 1998. National automotive sampling system (NASS) Crashworthiness Data System (CDS) Analytic User's Manual, 1997 File. Washington, D.C.: U.S. Department of Transportation.

National Highway Traffic Safety Administration. 1999a. FARS analytic reference guide, 1975-1998. DOT HS 808 792, Washington, D.C.: U.S. Department of Transportation.

National Highway Traffic Safety Administration. 1999b. National automotive sampling system (NASS) General Estimates System (GES), Analytical User's Manual, 1988-1997. Washington, D.C.: U.S. Department of Transportation.

Nation Highway Traffic Safety Administration. 1999c. State crash report forms catalog 1999 update. Washington, D.C.: U.S. Department of Transportation.

National Highway Traffic Safety Administration. 1999d. Traffic safety facts-1998. DOT HS 808 959. Washington, D.C.: U.S. Department of Transportation.

National Highway Traffic Safety Administration. 2001a. School bus safety: Safe passage for America's children. /injury/buses/schbus/schbussum.html. Accessed February 11, 2002.

National Highway Traffic Safety Administration. 2001b. Traffic safety facts-2000. DOT HS 809 337. Washington, D.C.: U.S. Department of Transportation.

National Transportation Safety Board. 1997. Highway accident/incident summary report, Collision with a pedestrian by a utility truck near Cosmopolis, Washington on November 26, 1996. Report PB97-916201, Washington, D.C.

Research Triangle Institute and Federal Highway Administration. 1997. $1995 \mathrm{Na-}$ tionwide Personal Transportation Survey, User's guide for the public use data files. Publication No. FHWA-PL-98-002 Washington, D.C.: U.S. Department of Transportation. 
U.S. Census Bureau. 2001. Statistical abstracts of the United States: 2001. $121^{\text {st }}$ ed. Washington, D.C.: U.S. Department of Commerce.

\section{About the Author}

LIDIA P. Kostyniuk (lidakost@umich.edu) is a research scientist in the Social and Behavioral Analysis Division at the University of Michigan Transportation Research Institute. She holds a Ph.D. in civil engineering and is a lice nsed professional engineer in the State of Michigan. Dr. Kostyniuk's research interests are in travel behavior, mobility, and transportation safety. 